\title{
Risk-based scoring and genetic identification for anisakids in frozen fish products from Atlantic FAO areas
}

\author{
Giorgio Smaldone ${ }^{1,2}$, Elvira Abollo ${ }^{3}$, Raffaele Marrone ${ }^{4 *}$ (D) Cristian E. M. Bernardi ${ }^{5}$, Claudia Chirollo ${ }^{4}$, \\ Aniello Anastasio ${ }^{2,4}$ and Santiago P. del Hierro ${ }^{6}$
}

\begin{abstract}
Background: The presence of Anisakis larvae in fish represents a major public health concern. Effective risk management procedures should be applied to prevent heavily infected products from reaching the market. The aim of the study is to provide preliminary data on parasite exposure and risk classification in frozen fish products by applying a risk categorization scheme (site, abundance, density and epidemiology - SADE) and Fish Parasite Rating (FPR) method. Fish and cephalopods samples $(\mathrm{N}=771)$ from 5 different FAO Atlantic areas were examined and categorized after an accurate visual inspection and a chloro-peptic digestion.

Results: In 25 out of 33 fish species parasite larvae were found. 10897 anisakids larvae were collected and identified to genus level. Molva dypterygia, Conger conger, Zeus faber and Aphanopus carbo were shown to be the most highly infected species. SADE and FPR scores were 1 and poor, respectively, for the referred species, because of the disseminated Anisakis infection and commercial rejection.

Conclusion: SADE/FPR method showed high specificity and accuracy. The information provided in this work could be used in early warning systems for the detection of parasites in fishery products and might help fishing industries in establishing management strategies for infected stocks in terms of cost saving decisions.
\end{abstract}

Keywords: Anisakis, food safety, risk ranking tool, zoonotic risk, fish inspection

\section{Background}

Nematodes of the Anisakidae family are fish parasites that can be found all around the world. The larvae live in the gut, visceral peritoneum and flesh of many marine fish and cephalopod species and can colonize through different trophic bridges ensuring and widening the parasite life cycle. Differences in host range, host specificity and pathogenetic potential, even among members of a given sibling species complex, have been historically suggested for anisakids [1-3]. Additionally, a positive relationship between body size/age of fish and larval nematode prevalence and/or abundance has been demonstrated in several commercially important fish species from different wild catch sea areas [4-7].

\footnotetext{
* Correspondence: raffaele.marrone@gmail.com

${ }^{4}$ Department of Veterinary Medicine and Animal Production, Unit of Food Hygiene, University of Naples, Federico II, via Delpino 1, 80137 Naples, Italy Full list of author information is available at the end of the article
}

Because no sea fishing grounds can be considered Anisakis free and the infection by anisakid larvae in fish is a natural condition and their complete eradication is not feasible [8], surveillance studies are of great interest to determine the risk exposure for those hot-spot geographic areas of parasite recruitment to fish production value chains. Moreover, nematodes of Anisakis genera are zoonotic parasites. In humans the ingestion of Anisakidae larvae can result in infection with live larvae, an allergic reaction to Anisakidae allergens or both [9-12]. The increased consumption of raw or undercooked fish constitutes an underestimated zoonotic potential risk [13-15]. In the last decade, Anisakis have been included among the biological hazards reported through the Rapid Alert System for Food and Feed (RASFF) of the European Commission, within the European Union (EU). 
European legislation [16] enforces an accurate visual inspection during the official control and in selfmonitoring programs to prevent fish borne zoonoses: in this context Food Business Operators (FBO) must ensure that no fishery products obviously contaminated with visible parasites reach the consumers. According to the "Guidance document on the implementation of certain provisions of Regulation (EC) No 853/2004 on the hygiene of food of animal origin" [17], a fishery product is considered obviously contaminated if visible parasites are found in edible portions; however, a maximum number of parasites was not defined. Furthermore, the application of visual inspection procedure in the fishery industry depends on the ability and training of FBO [18]. Because the presence of dead visible parasites could only represent a defect $[19,20]$ altering the global products quality and in order to comply with the EU prescriptions, in addition to the official control and selfmonitoring procedures, the most practical procedure could be the use of a predicting scheme for evaluation of nematode larvae in the edible part of the fish batches as suggested by the European Food Safety Authority (EFSA) [21]. The use of the SADE scheme (acronym of Site of infection; Assurance of quality; Demography density of parasites; Epidemiology of parasites) proposed by Llarena-reino et al., [22], combined with the Fish Parasite Rating (FPR) method [23], aimed at precisely evaluating the likely outcome of infected fish lots, which could be useful tools. FPR standard is a certified Community Trade Mark - Register No 012266607 at the Office for Harmonization in the Internal Market (OHIM) and provides the staging of fish lots, helping in planning manufacture, commercial, and research decisions during self-management programs. The aim of this research is to provide data on parasite risk exposure in commercial frozen fishery products collected in Atlantic FAO areas using the SADE scheme combined with FPR method in comparison with the official visual inspection procedure.

\section{Results}

\section{Parasites frequency in fish sub lots}

A total of eight fish species (24.24\% of sampled fish species/sub lots) were anisakid-free. Nematode larvae were not detected in Mallotus villosus, Glyptocephalus cynoglossus, Dicologlossa cuneata, Galeoides decadactylus, Trachurus trecae, Salilota australis, Atlantoraja castelnaui and Serranus cabrilla. A total of 10897 anisakid larvae were collected and identified to genus level in the flesh of 25 species. Among these species, M. dypterygia, C. conger, Z. faber and A. carbo, coming from FAO area 27 (Northeast Atlantic) were the most highly parasitized (Table 1) showing a total prevalence of infection (P) of $100 \%$ with a mean abundance (MA \pm SD) of $204.52 \pm$ 91.14, $115.16 \pm 96.77,44.96 \pm 32.66,74.1 \pm 28.55$ respectively. In these species, $90.45 \%$ of the total larvae were detected: in particular $M$. dypterygia reached the highest density of parasites (102.26 larvae/ kg). As much as $46.97 \%$ of total larvae in this species were detected. The statistical analyses indicate that there was a correlation between MA and fish sample mean weight $(p<0.001)$.

The hypaxial region was the most infected location. In fact, in 11 fish species, anisakid larvae were found only in this region and in general the $98.53 \%$ of larvae (n. 10737) were identified in this location. In $50 \%$ of the samples, the epaxial infection took place simultaneously with hypaxial location.

\section{Parasite frequency in fishing areas}

$\mathrm{P}$ of infection ( \pm CI 95\%) MA and mean intensity (MI) $( \pm$ SD) in the different fishing grounds of the study are reported in Table 2. No parasites were found in FAO area 34. Table 2 shows the comparison of $\mathrm{P}$ between different FAO areas: significative statistical differences $(p<$ 0.0001) between FAO areas were found. In this study, regarding $\mathrm{MA}$ and $\mathrm{MI}$, significative statistical differences between FAO area 27 and the other sampling areas were found $(p<0.001)$.

\section{Parasite identification}

The results show mixed infection in $45.83 \%$ of the fish sub lot examined. All sequences obtained in this study shared 99-100 \% nucleotide identity with other sequences of anisakid species deposited in the GenBank (accession ID and web links for each identified parasite, linked to fish species and FAO area, are indicated in the supplementary materials) belonging to Anisakis simplex sensu stricto, Anisakis pegreffii, Anisakis typica, Anisakis berlandi, Pseudoterranova cattani, Pseudoterranova decipiens s.l., Contracaecum osculatum s.l. and Hysterothylacium aduncum.

In this study $A$. simplex was the main parasite isolated in fishery products from FAO area 21 (100\%) and from FAO area $27(88.40 \%)$, while $A$. pegreffii was the main parasite isolated in fishery products from FAO area 41 $(65.9 \%)$ and from FAO area 47 (63.82\%). Fish collected from FAO area 41 showed the highest variability in terms of different species of parasites found.

\section{Risk categorisation}

Table 4 shows inspection data categorized by the SADE and FPR scoring systems. Using visual inspection, $36.36 \%$ of the lots didn't meet the EU standards [16] and were rejected. The rejected batches during the naked eye visual inspection present at least 1 visible larva in the edible portion. Over $66 \%$ of fish sub lots have been accepted as they present less than one parasite in the flesh, expressed as MA [24] (Table 1). MA, due to its correlation with $\mathrm{P}$ and with the number of samples [25], could 


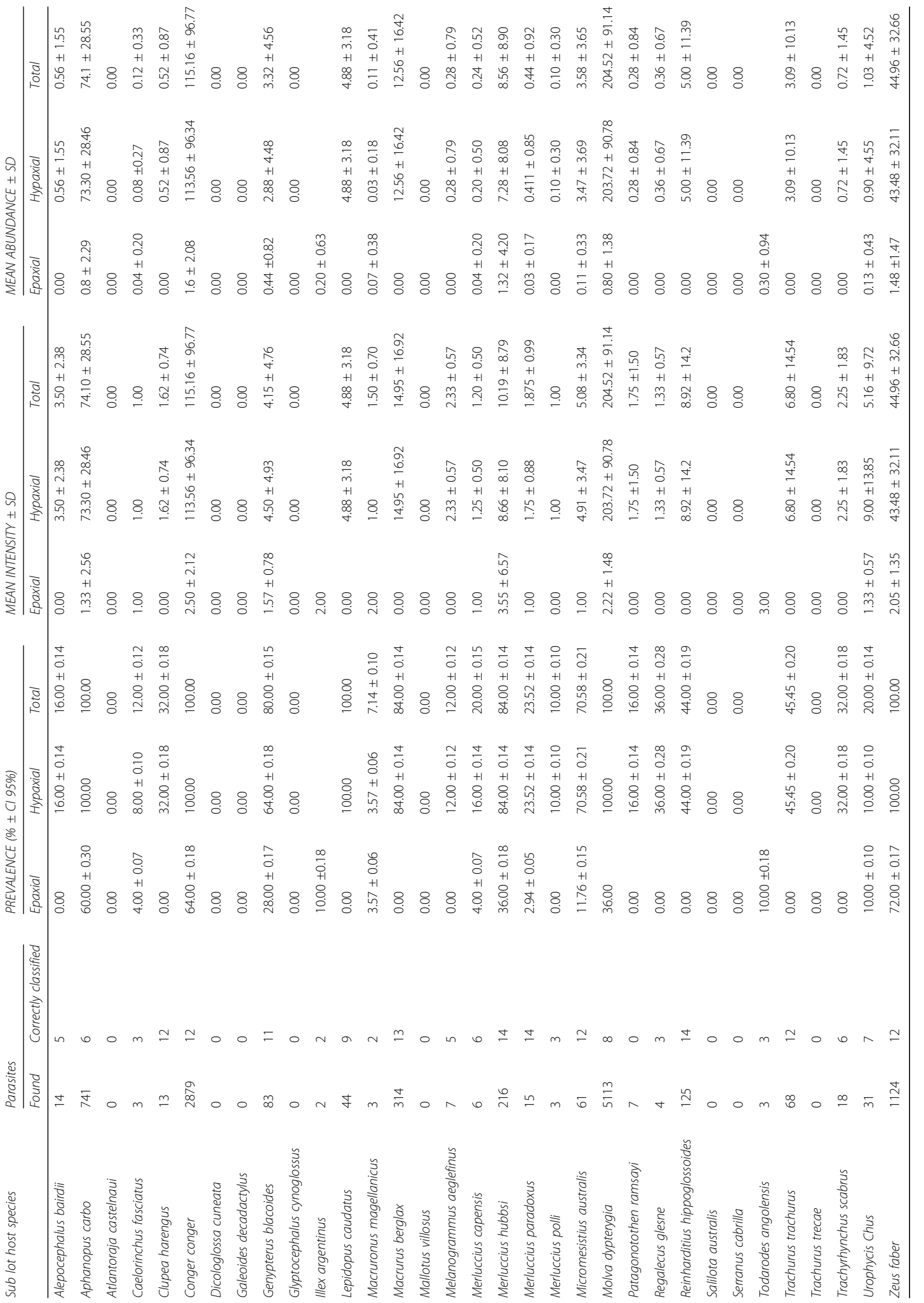


Table 2 FAO areas infection values according to Bush et al. 1997. Comparison of prevalence $\left(X^{2}\right)$ of infection between different FAO areas

\begin{tabular}{|c|c|c|c|c|c|c|c|c|c|c|}
\hline FAO areas & Individuals & Infected & $P(\%)$ & IC ( \pm$) 95 \%$ & $x^{2}$ & $p$ & MA & $\pm S D$ & Ml & $\pm S D$ \\
\hline Total sampling areas & 771 & 251 & 32.55 & 3.30 & 106.25 & $p<0.0001$ & 14.13 & 77.18 & 43.41 & 48.46 \\
\hline 21 & 130 & 41 & 31.53 & 7.98 & & & 3.61 & 10.07 & 11.46 & 15.33 \\
\hline 27 & 196 & 111 & 56.63 & 6.93 & & & 50.57 & 85.89 & 89.30 & 97.91 \\
\hline 34 & 100 & 0 & 0.00 & 0.00 & & & 0.00 & 0.00 & 0.00 & 0.00 \\
\hline 41 & 190 & 63 & 33.15 & 6.69 & & & 1.97 & 4.75 & 5.95 & 6.68 \\
\hline 47 & 155 & 36 & 23.22 & 6.64 & & & 0.89 & 4.10 & 3.86 & 7.89 \\
\hline
\end{tabular}

be used to estimate the degree of infestation [26], particurarly in the case of fishery products sold in batches. With regard to the naked eye rejected products, $33.33 \%$ of the total rejections belong to FAO 27. Not infected fish batches in FAO area 34 were found.

Using the SADE/FPR schemes, $27.27 \%$ of fish sub lots (M. hubbsi, M. australis, U. Chus, G. blacoides, M. paradoxus, A. carbo, Z. faber, C. conger, $M$. dypterygia) were assigned a low SADE score (from 1 to 3 ) corresponding to a "poor" FPR standard. Hence, these fish lots must be discarded. The lowest score (SADE 1) was assigned to $A$. carbo, Z. faber, C. conger and $M$. dypterygia, belonging to FAO 27, corresponding to the $44.44 \%$ of the total rejection. No statistical differences $(p=0.3711)$ between SADE/FPR outcomes and visual inspection were observed.

Finally, the non-zoonotic $H$. aduncum (Raphidascaridae) was also detected in I. argentinus: this parasite is generally considered not zoonotic, even if a case of invasive gastro-allergic infection was recently reported [27]. This result did not show differences in the application of SADE scoring system because a co-infection with the zoonotic A. simplex was noticed.

\section{Discussion}

\section{Parasites distribution}

The high frequency of parasites and MA observed in this study supports that Anisakis has the status of component parasite of many fish species and FAO fishing areas. Among the different species of Anisakis isolated, A. simplex commonly occurred in various ecologically and economically important fish species from Atlantic FAO areas 21, 27 and 41 (Atlantic Northwest, Northeast and Southwest) as reported by Mattiucci et al. [28]. A. pegreffii was found in southern Atlantic Ocean (FAO areas 41 and 47) and in FAO area 27 in agreement to previous studies [29-33]. According to Mattiucci et al. [34], A. typica can occur from $30^{\circ} \mathrm{S}$ to $35^{\circ} \mathrm{N}$ in warmer temperate and tropical waters and this data were confirmed by our findings (FAO area 47). Unlike Mattiucci [30] who highlighted a discontinuous range of distribution of this species including Pacific Canada, Chile, New Zealand waters and the Atlantic South African coast, A. berlandi was found only in South-Atlantic (FAO area 41 and
FAO area 47). P. decipiens s. 1., as reported by Szostakowska et al., [35], occurs sporadically and in our work only in 2 fish species were found (C. conger and Z. faber from FAO area 27) confirming that only parasites belonging to the $P$. decipiens complex are present in the NE Atlantic Ocean. P. cattani was found in G. blacoides from FAO area 41, in agreement with Timi et al. [36]. $H$. aduncum and C. osculatum s.l. were found only in FAO area 41 with low prevalence, in contrast to data reported by Niklitschek et al. [37] in the same sampling area in $\mathrm{N}=41$ samples of $M$. australis. Furthermore, in the same fish species caught in this area were found only parasites belonging to Anisakis genera.

Anisakis and Pseudoterranova are generally most abundant in European NE Atlantic waters [8]. These are traditionally some of the most productive fishing areas in Europe and the abundance of different hosts at all trophic levels presumably accounts for the overall abundance of the parasites. Differences in infection levels could also be related to the presence of definitive hosts or to host's feeding habits [1] and to the abundance of obligate intermediate crustacean and/or cephalopods hosts. M. dypterygia, C. Conger and Z. faber were the most highly infected species (rejected after visual inspection and with the lowest SADE/FPR scores), probably because of their relatively high trophic level in FAO area 27 ecosystems, their size $(p<0.05)$ and high quantity of food intake confirm that this fishing area had the strongest effect on larvae infection $[9,38]$.

Worst results corresponded to this fishing grounds with significative differences in $\mathrm{P}, \mathrm{MA}$ and $\mathrm{MI}$ match this area and the others $(p<0.0001)$. No statistical differences $(p>$ 0.05 ) between FAO areas with low MA and MI (FAO 21, FAO 34, FAO 41 and FAO 47, Table 3) were observed.

Moreover, the different spatial distribution in fish body of Anisakis infecting the same fish species could be influenced by Anisakis species. Cipriani et al. [7] noted that in M. merluccius from FAO area 27, A. simplex larvae outnumbers $A$. pegreffii larvae in the flesh of the same fish host; on the other hand, in the viscera the mean abundance of two larvae species was superimposable. This phenomenon could be the result of different resource utilization or linked to the different migrating 
Table 3 Number and percentage of parasites well sequenced collected in fishery products from different Atlantic areas

\begin{tabular}{|c|c|c|c|c|c|c|c|c|}
\hline & $\begin{array}{l}\text { A. simplex } \\
\text { (n./\%) }\end{array}$ & $\begin{array}{l}\text { A. pegreffii } \\
(n . / \%)\end{array}$ & $\begin{array}{l}\text { P. decipiens s. I. } \\
(n . / \%)\end{array}$ & $\begin{array}{l}\text { H. aduncum } \\
\text { (n./\%) }\end{array}$ & $\begin{array}{l}\text { A. berlandi } \\
(n . / \%)\end{array}$ & $\begin{array}{l}\text { A. typica } \\
(\mathrm{n} . / \%)\end{array}$ & $\begin{array}{l}\text { C. osculatum } \\
(n . / \%)\end{array}$ & $\begin{array}{l}\text { P. cattani } \\
\text { (n./\%) }\end{array}$ \\
\hline FAO 21 & $34 / 100 \%$ & $0 \%$ & $0 \%$ & $0 \%$ & $0 \%$ & $0 \%$ & $0 \%$ & $0 \%$ \\
\hline Urophycis Chus & $7 / 100 \%$ & $0 \%$ & $0 \%$ & $0 \%$ & $0 \%$ & $0 \%$ & $0 \%$ & $0 \%$ \\
\hline $\begin{array}{l}\text { Reinharditius } \\
\text { hippoglossoides }\end{array}$ & $14 / 100 \%$ & $0 \%$ & $0 \%$ & $0 \%$ & $0 \%$ & $0 \%$ & $0 \%$ & $0 \%$ \\
\hline Macrurus berglax & $13 / 100 \%$ & $0 \%$ & $0 \%$ & $0 \%$ & $0 \%$ & $0 \%$ & $0 \%$ & $0 \%$ \\
\hline FAO 27 & $61 / 88.40 \%$ & $2 / 2.89$ & $6 / 8.69$ & $0 \%$ & $0 \%$ & $0 \%$ & $0 \%$ & $0 \%$ \\
\hline Alepocephalus bairdii & $5 / 100 \%$ & $0 \%$ & $0 \%$ & $0 \%$ & $0 \%$ & $0 \%$ & $0 \%$ & $0 \%$ \\
\hline Conger conger & $6 / 50 \%$ & $1 / 8.33 \%$ & $5 / 41.66 \%$ & $0 \%$ & $0 \%$ & $0 \%$ & $0 \%$ & $0 \%$ \\
\hline Molva dypterygia & $8 / 100 \%$ & $0 \%$ & $0 \%$ & $0 \%$ & $0 \%$ & $0 \%$ & $0 \%$ & $0 \%$ \\
\hline Zeus faber & $11 / 91.66 \%$ & $0 \%$ & $1 / 8.33 \%$ & $0 \%$ & $0 \%$ & $0 \%$ & $0 \%$ & $0 \%$ \\
\hline Aphanopus carbo & $6 / 100 \%$ & $0 \%$ & $0 \%$ & $0 \%$ & $0 \%$ & $0 \%$ & $0 \%$ & $0 \%$ \\
\hline Trachyrhynchus scabrus & $6 / 100 \%$ & $0 \%$ & $0 \%$ & $0 \%$ & $0 \%$ & $0 \%$ & $0 \%$ & $0 \%$ \\
\hline Clupea harengus & $12 / 100 \%$ & $0 \%$ & $0 \%$ & $0 \%$ & $0 \%$ & $0 \%$ & $0 \%$ & $0 \%$ \\
\hline $\begin{array}{l}\text { Melanogrammus } \\
\text { aeglefinus }\end{array}$ & $5 / 100 \%$ & $0 \%$ & $0 \%$ & $0 \%$ & $0 \%$ & $0 \%$ & $0 \%$ & $0 \%$ \\
\hline Regalecus glesne & $2 / 66.66 \%$ & $1 / 33.33 \%$ & $0 \%$ & $0 \%$ & $0 \%$ & $0 \%$ & $0 \%$ & $0 \%$ \\
\hline FAO 41 & $1 / 2.27 \%$ & $29 / 65.9 \%$ & $0 \%$ & $1 / 2.27 \%$ & 8/18.18\% & $0 \%$ & $4 / 9.09 \%$ & $1 / 2.27 \%$ \\
\hline Micromesistius australis & $0 \%$ & $8 / 66.66 \%$ & $0 \%$ & $0 \%$ & $3 / 25 \%$ & 0 & $1 / 8.33 \%$ & $0 \%$ \\
\hline Genypterus blacoides & $0 \%$ & $7 / 63.63 \%$ & $0 \%$ & $0 \%$ & $3 / 27.27 \%$ & $0 \%$ & $0 \%$ & $1 / 9.09 \%$ \\
\hline Merluccius hubbsi & $0 \%$ & $10 / 71.42 \%$ & $0 \%$ & $0 \%$ & $1 / 7.14 \%$ & $0 \%$ & $3 / 21.42 \%$ & $0 \%$ \\
\hline Caelorinchus fasciatus & $0 \%$ & $2 / 66.66 \%$ & $0 \%$ & $0 \%$ & $1 / 33.33 \%$ & $0 \%$ & $0 \%$ & $0 \%$ \\
\hline $\begin{array}{l}\text { Macruronus } \\
\text { magellanicus }\end{array}$ & $0 \%$ & $2 / 100 \%$ & $0 \%$ & $0 \%$ & $0 \%$ & $0 \%$ & $0 \%$ & $0 \%$ \\
\hline Illex argentinus & $1 / 50 \%$ & $0 \%$ & $0 \%$ & $1 / 50 \%$ & $0 \%$ & $0 \%$ & $0 \%$ & $0 \%$ \\
\hline FAO 47 & $0 \%$ & $30 / 63.82 \%$ & $0 \%$ & $0 \%$ & $5 / 10.63 \%$ & $12 / 25.53 \%$ & $0 \%$ & $0 \%$ \\
\hline Trachurus trachurus & $0 \%$ & $12 / 100 \%$ & $0 \%$ & $0 \%$ & $0 \%$ & $0 \%$ & $0 \%$ & $0 \%$ \\
\hline Lepidopus caudatus & $0 \%$ & $0 \%$ & $0 \%$ & $0 \%$ & $0 \%$ & $9 / 100 \%$ & $0 \%$ & $0 \%$ \\
\hline Merluccius paradoxus & $0 \%$ & $13 / 92.86 \%$ & $0 \%$ & $0 \%$ & $0 \%$ & $1 / 7.14 \%$ & $0 \%$ & $0 \%$ \\
\hline Merluccius capensis & $0 \%$ & $5 / 83.33 \%$ & $0 \%$ & $0 \%$ & $1 / 16.66 \%$ & $0 \%$ & $0 \%$ & $0 \%$ \\
\hline Todarodes angolensis & $0 \%$ & $0 \%$ & $0 \%$ & $0 \%$ & $3 / 100 \%$ & $0 \%$ & $0 \%$ & $0 \%$ \\
\hline Merluccius polli & $0 \%$ & $0 \%$ & $0 \%$ & $0 \%$ & $1 / 33 \%$ & 2/66.66\% & $0 \%$ & $0 \%$ \\
\hline
\end{tabular}

ability of the Anisakis species because of different abilities of the two species to respond to the fish host's immune system [39].

\section{Safety and quality considerations}

Our study confirms the presence of anisakid species with public health implications in lots of fishery products from different FAO areas. Although freezing condition and other treatments as salting and spicing assure no viable larvae in the fish products [40-43], the risk of allergens in the edible part of fish for hypersensitive individuals should be highlighted. EU legislation [44] recognizes that any parasitized fish under a visual inspection scheme should be unfit for human consumption. Comparing predictive schemes and visual inspection, in general the highest scores were associated with the acceptance of the fish batches as stated by the EU legislation. A different situation was found in the case of some batches: 7 fish sublots reached SADE score 4, corresponding to a "fair" FPR standard. "Fair" fish batches have neither pathological nor commercial problems (A2 SADE code - Table 4) and FBO have the possibility to give different final destinations to these fish lots, as processing, assuring safety and cost saving. Under visual inspection 4 "fair" fish batches were rejected because of the number of parasites detected (MA over 3, high parasite density - D0 SADE code) despite the absence of flesh alterations. This approach matches the precautionary principle set by Reg. EU 178/02 [20] but was restrictive in terms of economics gain. As stated by EU Reg. 853/04, FBO have to ensure that the product to 
Table 4 Inspection data categorized by the SADE and FPR scoring systems

\begin{tabular}{|c|c|c|c|c|c|c|c|c|}
\hline \multirow[t]{2}{*}{ Host } & \multicolumn{3}{|c|}{$\begin{array}{l}\text { Density } \\
\text { (n. larvae/kg) }\end{array}$} & \multirow{2}{*}{$\begin{array}{l}\text { Visual } \\
\text { inspection } \\
\text { outcome }\end{array}$} & \multirow[t]{2}{*}{$\begin{array}{l}\text { SADE } \\
\text { code }\end{array}$} & \multirow[t]{2}{*}{ Score } & \multirow[t]{2}{*}{$\begin{array}{l}\text { FPR } \\
\text { score }\end{array}$} & \multirow[t]{2}{*}{$\begin{array}{l}\text { FAO } \\
\text { Areas }\end{array}$} \\
\hline & Epaxial & Hypaxial & Total & & & & & \\
\hline Atlantoraja castelanui & 0 & 0 & 0 & Accepted & S3A2D2E3 & 10 & Excellent & 41 \\
\hline Dicologlossa cuneata & 0 & 0 & 0 & Accepted & S3A2D2E3 & 10 & Excellent & 34 \\
\hline Galeoides decadactylus & 0 & 0 & 0 & Accepted & S3A2D2E3 & 10 & Excellent & 34 \\
\hline Glyptocephalus cynoglossus & 0 & 0 & 0 & Accepted & S3A2D2E3 & 10 & Excellent & 21 \\
\hline Mallotus villosus & 0 & 0 & 0 & Accepted & S3A2D2E3 & 10 & Excellent & 21 \\
\hline Salilota australis & 0 & 0 & 0 & Accepted & S3A2D2E3 & 10 & Excellent & 41 \\
\hline Serranus cabrilla & 0 & 0 & 0 & Accepted & S3A2D2E3 & 10 & Excellent & 47 \\
\hline Trachurus trecae & 0 & 0 & 0 & Accepted & S3A2D2E3 & 10 & Excellent & 34 \\
\hline Trachyrhynchus scabrus & 0 & 4.80 & 4.80 & Accepted & S2A2D1E0 & 7 & Good & 27 \\
\hline Illex argentinus & & & 0.44 & Accepted & S3A2D2E0 & 7 & Good & 41 \\
\hline Todarodes angolensis & & & 1 & Accepted & S3A2D2E0 & 7 & Good & 47 \\
\hline Clupea harengus & 0 & 1.73 & 1.73 & Accepted & S2A2D2E0 & 6 & Good & 27 \\
\hline Patagonotothen ramsayi & 0 & 1.4 & 1.4 & Accepted & S2A2D2E0 & 6 & Good & 41 \\
\hline Melanogrammus aeglefinus & 0 & 0.80 & 0.80 & Accepted & S2A2D2E0 & 6 & Good & 27 \\
\hline Alepocephalus bairdii & 0 & 0.56 & 0.56 & Accepted & S2A2D2E0 & 6 & Good & 27 \\
\hline Merluccius polli & 0 & 0.50 & 0.50 & Accepted & S2A2D2E0 & 6 & Good & 47 \\
\hline Regalecus glesne & 0 & 0.45 & 0.45 & Accepted & S2A2D2E0 & 6 & Good & 27 \\
\hline Lepidopus caudatus & 0 & 9.70 & 9.70 & Rejected & S2A2D0E0 & 4 & Fair & 47 \\
\hline Trachurus trachurus & 0 & 7.72 & 7.72 & Rejected & S2A2D0E0 & 4 & Fair & 47 \\
\hline Reinharditius hippoglossoides & 0 & 7.14 & 7.14 & Rejected & S2A2D0E0 & 4 & Fair & 21 \\
\hline Macrurus berglax & 0 & 41.86 & 41.86 & Rejected & S2A2D0E0 & 4 & Fair & 21 \\
\hline Merluccius capensis & 0.22 & 1.14 & 1.37 & Accepted & SOA2D2E0 & 4 & Fair & 47 \\
\hline Caelorinchus fasciatus & 0.13 & 0.26 & 0.40 & Accepted & SOA2D2E0 & 4 & Fair & 41 \\
\hline Macruronus magellanicus & 0.14 & 0.07 & 0.21 & Accepted & SOA2D2E0 & 4 & Fair & 41 \\
\hline Merluccius hubbsi & 0.73 & 4.06 & 4.80 & Rejected & SOA2D1E0 & 3 & Poor & 41 \\
\hline Micromesistius australis & 0.13 & 4.09 & 4.23 & Rejected & SOA2D1E0 & 3 & Poor & 41 \\
\hline Urophycis Chus & 0.48 & 3.27 & 3.75 & Rejected & SOA2D1E0 & 3 & Poor & 21 \\
\hline Genypterus blacoides & 0.44 & 2.88 & 3.32 & Rejected & SOA2D1E0 & 3 & Poor & 41 \\
\hline Merluccius paradoxus & 0.16 & 2.35 & 2.52 & Accepted & SOA2D1E0 & 3 & Poor & 47 \\
\hline Aphanopus carbo & 1 & 91.62 & 92.62 & Rejected & S0A1D0E0 & 1 & Poor & 27 \\
\hline Zeus faber & 2.46 & 72.46 & 74.93 & Rejected & SOA1D0E0 & 1 & Poor & 27 \\
\hline Conger conger & 0.64 & 45.42 & 46.06 & Rejected & SOA1D0E0 & 1 & Poor & 27 \\
\hline Molva dypterygia & 0.40 & 101.86 & 102.26 & Rejected & SOA1D0E0 & 1 & Poor & 27 \\
\hline
\end{tabular}

be presented to the consumer is not obviously contaminated with parasites by visual inspection. Since there were different interpretations of concepts like "viable parasite" and "obviously contaminated" $[16,44-46]$ with a lack of standard regarding the maximum parasite limit allowed in a fish, the implementation of this risk-based surveillance according to the system developed by Llarena-Reino et al. [22] matching SADE scheme with FPR standards, should make it easier to categorize the public health and economic risk of anisakids in the flesh of commercial fish.
In this study the highest rejection rate of fish lots was under visual inspection, penalizing in some cases the FBO. SADE/FPR rejection was higher than visual inspection only in a few cases, especially for products heavily infected with deep embed larvae in which parasites were difficult to detect because of the fat percentage and colour of the viscera. However, this should be important for fish industry: in our findings, in fact, among lots with low scores, there are several fish species used for processed products of high value. 
In fact, $M$. dypterygia is used for deep or light salted products and M. hubbsi, M. capensis and M. paradoxus are the most used species for fish sticks. According to EU legislation [16], M. paradoxus would not have been rejected because of the low number of deep embed larvae not detectable by naked eye inspection. These sub lots, according to the scheme adopted, were rejected to prevent food business operator to suffer serious commercial losses.

This work aims to present the application of the above mentioned method on fishery products coming from several Atlantic FAO areas. Recently Rodriguez et al. [23], according to the SADE/FPR scheme, examined fish caught from 3 different ICES areas (ICES VII - Grand Sole, ICES VIII - Galician coast and ICES IX - Portuguese coast) located in the same FAO area (NE Atlantic areas - FAO 27). These authors gave "poor" FPR score to only 2 fish species, $M$. merluccius (ICES VII and ICES VIII) and Lophius budegassa (ICES VII), of the 9 examined, differently from our results where several fish species (A. carbo, Z. faber, C. conger, $M$. dypterygia), caught in NE Atlantic areas, reached SADE 1 and consequently "poor" FPR score.

The combined scoring systems are less restrictive than visual inspection: results compared between the different methods could be helpful to analyse an appropriate balance in terms of consumer's safety and FBO interests. The SADE/FPR method has an acceptable sensitivity (66.7\%; CI95\% 34.8 - 90.1\%) but a high specificity (95.2\%; CI95\% 76.2 - 99.9\%). The accuracy of $84.85 \%$ (CI95\% 68.1 - 94.9\%) indicates that the SADE/FPR method has a high capacity to correctly classify fishery products. This predictive scheme, proposing corrective measures within HACCP procedures, proved to be very useful for fish lots with the lowest FPR rating particularly and offers a crucial food safety device for assessing risks associated with parasites.

\section{Conclusion}

SADE score combined with FPR standard may represent a specific low-cost tool in fish inspection, ensuring both safety and quality, that could be useful for competent authorities and fish industry operators to establish standard management strategies. The categorization of lots in 5 quality batches, allowing the possibility of calculating accurately both parasitic load and flesh integrity, could give a unique language and modus operandi during self-control inspections in HACCP procedures and programs addressing fish lots in different ways depending on the score. The high specificity and accuracy of the applied predictive tests guarantees its correct applicability during the fish inspection procedures.

\section{Methods}

Sampling

Between May and October 2013, a total of 771 fish and cephalopods frozen samples belonging to several commercial frozen lots (33 different species) from 5 different Atlantic FAO fishing areas (Table 5) were examined in the laboratories of the Instituto de Investigaciones Marinas de Vigo - Ecobiomar Department. FAO Fishing areas (Fig. 1) where fishery products were sampled as FAO 21 (Atlantic, Northwest, $\mathrm{N}=130$ individuals - 5 different species), FAO 27 (Atlantic, Northeast, $\mathrm{N}=196$ individuals - 9 different species), FAO 34 (Atlantic, Eastern Central, $\mathrm{N}=100$ individuals -3 different species), FAO 41(Atlantic, Southwest, N=190 individuals 9 different species) and FAO 47 (Atlantic, Southwest, $\mathrm{N}=139$ individuals -7 different species). According to Reg. EC 2074/05, a representative number of samples underwent visual inspection; for each lot (number of fish/box and number of boxes harvested by vessels that compose the lot is shown in Table 5) a representative sample (sub lot) was taken, ranging from $12 \%$ for Merluccius polli to $100 \%$ for Aphanopus carbo).

\section{Visual inspection}

After thawing, each sub lot was weighed, each sample was weighed individually, and the abdominal cavity of each sample was opened and kept under a down-light source. The samples were gutted and the celomatic cavity was briefly inspected by the naked eye, for the presence of nematodes. According to EFSA recommendations [8], the presence of potentially zoonotic anisakid species was evaluated only in the edible parts of fishery products that is considered the main exposure risk factor for the consumer. Guts are usually discarded during fish-processing procedures. The presence of parasites on visceral peritoneum was checked but not considered a serious factor because the freezing condition prevents the migration of parasites in the flesh. For this reason, viscera were not analyzed, only the edible part of the products were considered.

\section{Artificial peptic digestion}

After visual inspection heads and tails were removed. The remaining musculature was dissected in left and right fillets and then separated into the hypaxial (ventral) and epaxial (dorsal) regions following the horizontal septum. In case of cephalopods, the body cavity was opened and a macroscopic visual inspection was carried out.

The whole muscle (hypaxial and epaxial regions separately) of each fish sample was digested in an ACM-11806 Magnetic Stirrer Multiplate in pepsin solution [47]. For cephalopods, the mantle muscle was used to perform the process. Digestions were performed for 30 minutes at 
Table 5 Samples collected from Atlantic FAO areas

\begin{tabular}{|c|c|c|c|c|}
\hline FAO fishing areas & Coordinates & Host & N. boxes / total fish count & Individuals sampled (N) \\
\hline FAO 21 Atlantic, Northwest & & Glyptocephalus cynoglossus & $1 / 60$ & 25 \\
\hline FAO 21 Atlantic, Northwest & $48^{\circ} 38^{\prime} \mathrm{N} 45^{\circ} 43^{\prime} \mathrm{W}$ & Macrurus berglax & $2 / 50$ & 25 \\
\hline FAO 21 Atlantic, Northwest & $46^{\circ} 51^{\prime} \mathrm{N} 47^{\circ} 20^{\prime} \mathrm{W}$ & Mallotus villosus & $1 / 50$ & 25 \\
\hline FAO 21 Atlantic, Northwest & $48^{\circ} 33^{\prime} \mathrm{N} 45^{\circ} 45^{\prime} \mathrm{W}$ & Reinharditius hippoglossoides & $8 / 109$ & 25 \\
\hline FAO 21 Atlantic, Northwest & $48^{\circ} 38^{\prime} N 45^{\circ} 42^{\prime} W$ & Urophycis chus & $4 / 114$ & 30 \\
\hline FAO 27 Atlantic, Northeast & $56^{\circ} 13^{\prime} \mathrm{N} 17^{\circ} 34^{\prime} \mathrm{W}$ & Alepocephalus bairdii & $7 / 52$ & 25 \\
\hline FAO 27 Atlantic, Northeast & $56^{\circ} 13^{\prime} \mathrm{N} 17^{\circ} 35^{\prime} \mathrm{W}$ & Aphanopus carbo & $1 / 10$ & 10 \\
\hline FAO 27 Atlantic, Northeast & FAO $27 \| a$ & Clupea harengus & $2 / 100$ & 25 \\
\hline FAO 27 Atlantic, Northeast & FAO 27/ VII & Conger conger & $6 / 100$ & 25 \\
\hline FAO 27 Atlantic, Northeast & & Melanogrammus aeglefinus & $1 / 50$ & 25 \\
\hline FAO 27 Atlantic, Northeast & $54^{\circ} 34^{\prime} \mathrm{N} 17^{\circ} 59^{\prime} \mathrm{W}$ & Molva dypterygia & $11 / 71$ & 25 \\
\hline FAO 27 Atlantic, Northeast & $58^{\circ} 38^{\prime} \mathrm{N} 15^{\circ} 04^{\prime} \mathrm{W}$ & Regalecus glesne & $2 / 11$ & 11 \\
\hline FAO 27 Atlantic, Northeast & FAO 27/XII & Trachyrhynchus scabrus & $2 / 100$ & 25 \\
\hline FAO 27 Atlantic, Northeast & & Zeus faber & $1 / 50$ & 25 \\
\hline FAO 34 Atlantic, Eastern Central & & Dicologlossa cuneata & $2 / 50$ & 25 \\
\hline FAO 34 Atlantic, Eastern Central & $12^{\circ} 50^{\prime} \mathrm{N} 17^{\circ} 25^{\prime} \mathrm{W}$ & Galeoides decadactylus & $5 / 50$ & 25 \\
\hline FAO 34 Atlantic, Eastern Central & $13^{\circ} 00^{\prime} \mathrm{N} 17^{\circ} 15^{\prime} \mathrm{W}$ & Trachurus trecae & $2 / 60$ & 50 \\
\hline FAO 41 Atlantic, Southwest & & Atlantoraja castelanui & $8 / 50$ & 10 \\
\hline FAO 41 Atlantic, Southwest & & Caelorinchus fasciatus & $1 / 50$ & 25 \\
\hline FAO 41 Atlantic, Southwest & & Genypterus blacoides & $3 / 50$ & 25 \\
\hline FAO 41 Atlantic, Southwest & & Illex argentinus & $3 / 50$ & 10 \\
\hline FAO 41 Atlantic, Southwest & & Macruronus magellanicus & $9 />200$ & 28 \\
\hline FAO 41 Atlantic, Southwest & & Merluccius hubbsi & $6 / 50$ & 25 \\
\hline FAO 41 Atlantic, Southwest & & Micromesistius australis & $3 / 50$ & 17 \\
\hline FAO 41 Atlantic, Southwest & & Patagonotothen ramsayi & $1 / 50$ & 25 \\
\hline FAO 41 Atlantic, Southwest & & Salilota australis & $2 / 50$ & 25 \\
\hline FAO 47 Atlantic, Southeast & $13^{\circ} 37,09512^{\circ} 17,38^{\prime} E$ & Lepidopus caudatus & $1 / 25$ & 9 \\
\hline FAO 47 Atlantic, Southeast & $23^{\circ} 21,5^{\prime} S 13^{\circ} 22,3^{\prime} E$ & Merluccius capensis & $1 / 36$ & 25 \\
\hline FAO 47 Atlantic, Southeast & $27^{\circ} 11,2^{\prime \prime} \mathrm{S} 14^{\circ} 22,5^{\prime} E$ & Merluccius paradoxus & $1 / 50$ & 34 \\
\hline FAO 47 Atlantic, Southwest & $11^{\circ} 48,84 S 13^{\circ} 22,97^{\prime} \mathrm{E}$ & Merluccius polli & $12 />250$ & 30 \\
\hline FAO 47 Atlantic, Southeast & $25^{\circ} 53,1^{\prime} \mathrm{S} 13^{\circ} 41,7 \mathrm{~W}$ & Serranus cabrilla & $1 / 50$ & 25 \\
\hline FAO 47 Atlantic, Southeast & $27^{\circ} 03,8514^{\circ} 14,7 E$ & Todarodes angolensis & $3 / 50$ & 10 \\
\hline FAO 47 Atlantic, Southeast & $24^{\circ} 10,9513^{\circ} 31,0^{\prime} E$ & Trachurus trachurus & $2 / 50$ & 22 \\
\hline
\end{tabular}

incubation temperature of $37^{\circ} \mathrm{C}$ in an acid solution $(\mathrm{pH}=$ 1.5) with $\mathrm{HCl} 0.063 \mathrm{M}$. Assays using liquid pepsin at concentration of $0.5 \%$ and a ratio 1:20 sample weight/solution volume were used. The digestion solution was decanted through a sieve and the rests of digestion and nematodes were inspected under stereomicroscope. All anisakids were placed in individual eppendorf with ethanol $70 \%$ for further molecular diagnosis.

\section{Molecular analysis}

All anisakid larvae were identified at genus level by microscopic examination of diagnostic characters. The biomolecular identification was performed by randomly choosing 15 larvae per species; in sub lots/species with a number of parasites lower than 15, all larvae were analyzed. A total of 275 anisakid larvae, previously identified at genus level, were used for molecular identification but only 194 were correctly classified by biomolecular analysis (Table 1). DNA extractions were performed using the commercial kit NucleoSpin ${ }^{\oplus}$ Tissue kit (MachereyNagel) following the manufacturer's recommended protocols. DNA quality and quantity were checked in a spectrophotometer Nanodrop ${ }^{\circ}$ ND-1000 (Nanodrop technologies, Inc). The entire ITS (ITS1, 5.8S rDNA 


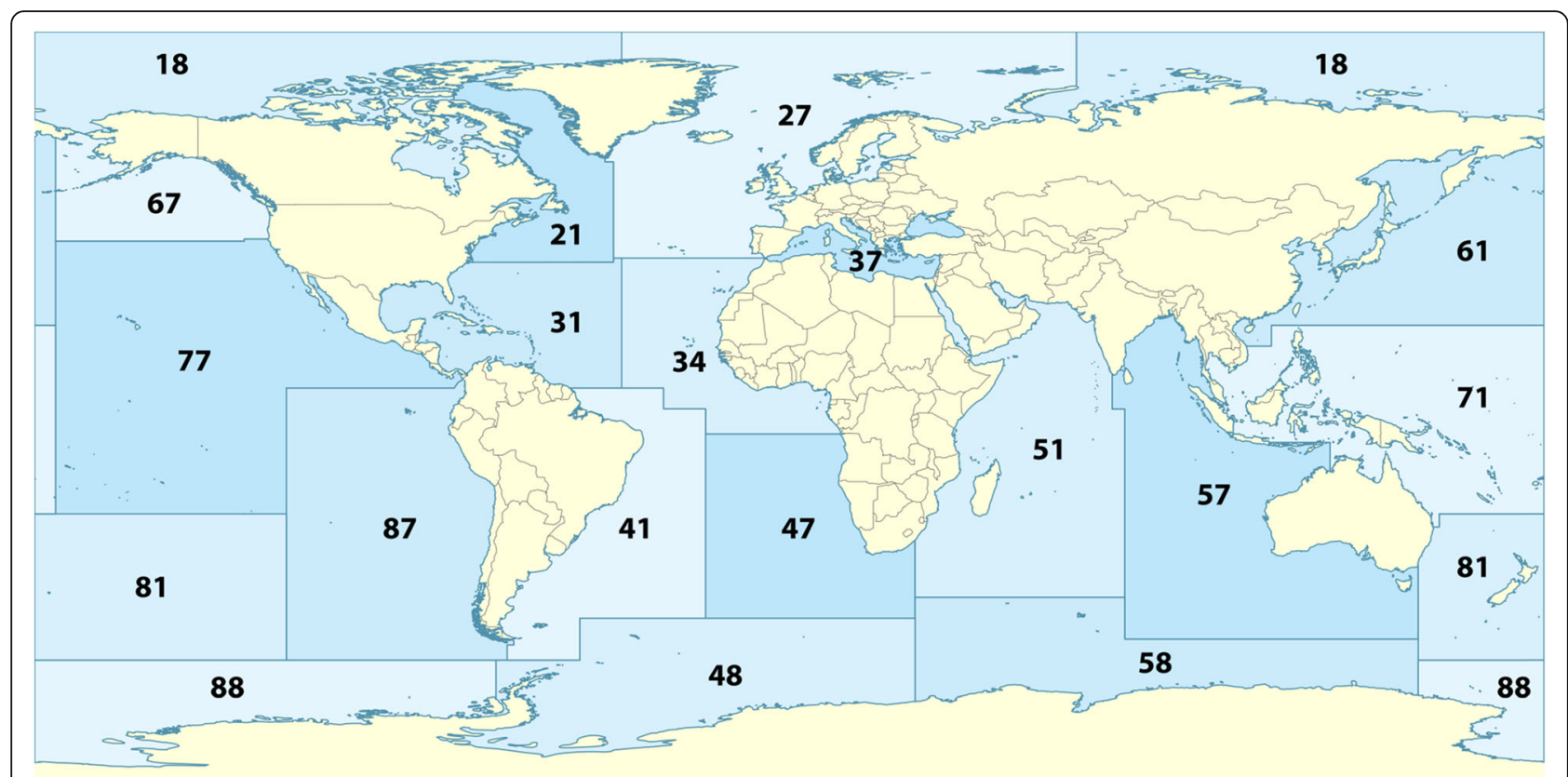

Fig. 1 Global map of FAO Major Fishing Areas. (https://commons.wikimedia.org/w/index.php?search=fao+areas\&title=Special\%3ASearch\&go=Go \&ns $0=1 \& n s 6=1 \& n s 12=1 \& n s 14=1 \& n s 100=1 \& n s 106=1 \# /$ media/File:FAO_Major_Fishing_Areas.svg)

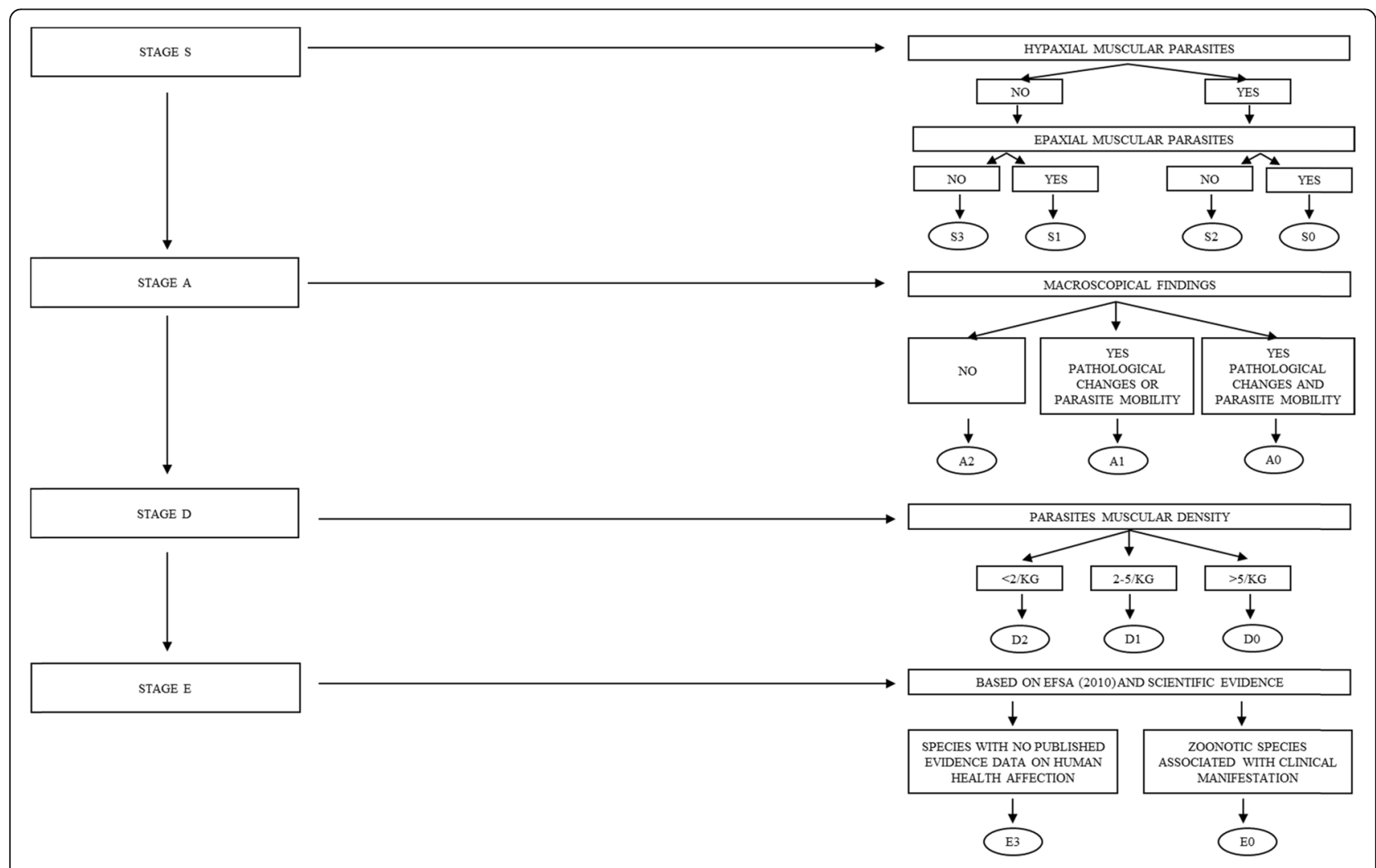

Fig. 2 Flow diagram for the Site of infection, Assurance of quality, Demography, Epidemiology (SADE) modified according to Llarena-reino et al., 2013 
gene and ITS2) was amplified using the forward primer NC5 (5'-GTA GGT GAA CCT GCG GAA GGA TCA TT-3') and the reverse primer NC2 (5'-TTA GTT TCT TTT CCT CCG CT-3'). PCR assays were carried out in a total volume of $25 \mu \mathrm{l}$ containing $100 \mathrm{ng}$ of genomic DNA, $0.3 \mu \mathrm{M}$ of each primer, $2.5 \mu \mathrm{l}$ of $10 \mathrm{x}$ buffer, 1.5 $\mathrm{mM}$ of $\mathrm{MgCl}_{2}, 0.2 \mathrm{mM}$ of dNTPs and $0.625 \mathrm{U}$ of Taq DNA polymerase (Roche Mannheim, Germany). PCR cycling parameters included denaturation at $94^{\circ} \mathrm{C}$ for 2 min, followed by 35 cycles of $94{ }^{\circ} \mathrm{C}$ for $30 \mathrm{~s}$, annealing at $55{ }^{\circ} \mathrm{C}$ for $30 \mathrm{~s}$, and extension at $72{ }^{\circ} \mathrm{C}$ for $75 \mathrm{~s}$, and a final extension at $72{ }^{\circ} \mathrm{C}$ for $7 \mathrm{~min}$. PCR products were purified for sequencing using ExoSAP-IT (c) following recommended protocol by the manufacturer. Sequencing was performed by Secugen (Madrid, Spain) and the electropherograms were analysed using the program ChromasPro version 1.41 Technelysium Pty LtdA. All sequences were searched for similarity using BLAST (Basic Local Alignment Search Tool) through web servers of the National Center for Biotechnology Information (USA).

\section{Risk categorisation}

Briefly sub lots are grouped according to four homogeneous categories named S, A, D, and E, that are afterwards split into numeric subcategories by the means of a flow diagram (Fig. 2 modified according to Llarena-reino et al., [22]): each inspected fish lot was categorized according to the localization of parasites $(\mathrm{S}-$ hypaxial or epaxial musculature flesh), the presence/absence of pathological or unaesthetic signs in the edible part (A), the density of infection ( $\mathrm{D}$ - number of larvae/ $\mathrm{kg}$ of fish) and finally the epidemiological relevance of the parasites ( $E$ - zoonotic or not). By adding the numeric values of each categories, the SADE system adopts a 10-point scale: as a result, a SADE code and a final score are obtained for each lot checked, in order to decide the final destination.

The highest values indicate no risk connected to the examined lots, whereas the lowest score suggests serious issues connected to fish parasites.

These preliminary results were translated to the standard Fish Parasite Rating (FPR) score, which allows the classification of fish lots into five categories (Fig. 3):

- Poor: final score 0-3;

- Fair: final score 4-5;

- Good: final score 6-7

- Very good: final score 8-9;

- Excellent: final score 10.

Since the SADE scheme is used for the evaluation of homogenous commercial fish lots, the scientists who took part in the study did not proceed to the individual measurement of the sample. The products were only weighed in order to assess the parasitic density (n. Parasites / kg). 
Finally, according to the European Hygiene Rules (Reg. EC 853/2004, Section VIII, Chapter V, Pt. D), the percentage of fishery products that should be unfit for human consumption was calculated and compared with SADE - FPD scores.

\section{Statistical analysis}

To describe parasite population the following parameters were used, according to Bush et al. [24]: P (the ratio between parasitized subjects/sub lots and the total subjects/ sub lots analysed), MA (the ratio between the number of larvae recovered and the number of all examined subjects of sub lots) and MI (the ratio between the number of larvae recovered and the number of examined parasitized subjects of sub lots). Infection indexes were calculated regardless of parasites' localisation site (Epaxial/Hypaxial flesh), species/sub lot and for each FAO areas. The differences in the P between FAO areas were assessed by the two-sided chi-square test.

Statistical significance between MA and MI of different FAO Areas was performed using One-way ANOVA with Bonferroni's post-test.

In order to assess statistical association between MA and fish sample mean weight a simple regression analysis was used. Finally, statistical comparisons between SADE/FPR and Visual Inspection were performed by McNemar's chi-square test [48]. Moreover, sensitivity, specificity and accuracy values of the SADE/FPR relative to Visual Inspection were calculated. Statistical analyses were performed using GraphPad InStat Version 3.0 (GraphPad Software, San Diego California USA) and MedCalc for Windows, version 18.11.3 (MedCalc Software, Ostend, Belgium); $p<0.05$ was considered significant for all statistical tests.

\section{Supplementary information}

Supplementary information accompanies this paper at https://doi.org/10. 1186/s12917-020-02286-7.

Additional file 1. Identified parasites in fish species,Accession ID related to the aligned sequences and web links (https://www.ncbi.nlm.nih.gov/ pubmed/)

\section{Abbreviations \\ EFSA: European Food Safety Authority; EU: European Union; EU: European Union; FAO: Food and Agriculture Organization of the United Nations; FBO: Food Business Operators; FPR: Fish Parasite Rating; HACCP: Hazard Analysis and Critical Control Points; ICES: International Council for the Exploration of the Sea; MA: Mean abundance; MI: Mean intensity; OHIM: Office for Harmonization in the Internal Market; P: Prevalence of infection; RASFF: Rapid Alert System for Food and Feed; SADE: Site, abundance, density and epidemiology}

\section{Acknowledgements}

We would like to thank the Instituto de Investigaciones Marinas de Vigo Consejo Superior de Investigaciones Científicas (IIM-CSIC) and the all team of Department of Ecology and Marine Biodiversity (ECOBIOMAR) for the human and technical support during the study.

\section{Authors' contributions}

GS and SP designed the overall study; EA and CC developed the molecular protocol. GS performed parasites inspection in fishery products and morphological identification of anisakid samples. AA, RM and SP analysed the results and drafted the paper. SP, CB and GS contributed to the ideas behind the study and the writing of the paper. All authors critically reviewed the paper and agreed the final content of the version to be published. The author(s) read anda pproved the final manuscript

\section{Funding}

This work has been partially supported by the Istituto Zooprofilattico Sperimentale della Sicilia - granted project "Indagine epidemiologica sulla prevalenza di allergie da Anisakis nella Regione Sicilia".

\section{Availability of data and materials}

The datasets used and/or analyzed during the current study are available from the corresponding author on reasonable request. Sequencing was performed by Secugen (Madrid, Spain) and the electropherograms were analysed using the program ChromasPro version 1.41 Technelysium Pty LtdA. All sequences were searched for similarity using BLAST (Basic Local Alignment Search Tool) (https://blast.ncbi.nlm.nih.gov/Blast.cgi). Accession ID were in the supplementary materials.

Ethics approval and consent to participate

Not applicable.

\section{Consent for publication}

Not applicable.

\section{Competing interests}

The authors declare that they have no competing interests.

\section{Author details}

'Department of Agricultural Sciences, University of Naples, Federico II, via Università 100, 80055 Naples, Portici (NA), Italy. ${ }^{2}$ Centro di Riferimento Regionale per la Sicurezza Sanitaria del Pescato CRiSSaP, Naples, Campania Region, Italy. ${ }^{3}$ Centro Tecnológico del Mar - Fundación CETMAR, C/Eduardo Cabello s/n, 36208 (Pontevedra), Vigo, Spain. ${ }^{4}$ Department of Veterinary Medicine and Animal Production, Unit of Food Hygiene, University of Naples, Federico II, via Delpino 1, 80137 Naples, Italy. ${ }^{5}$ Department of Veterinary Science and Technologies for Food Safety, Laboratory of Food Inspection, Università degli Studi di Milano, Via A. Grasselli, 7-20137, Milano, Italy. ${ }^{6}$ Ecobiomar - Instituto de Investigaciones Marinas de Vigo - CSIC - C/ Eduardo Cabello 6, 36208 (Pontevedra), Vigo, Spain.

Received: 24 January 2019 Accepted: 13 February 2020

Published online: 21 February 2020

\section{References}

1. Mattiucci S, Cipriani P, Webb SC, Paoletti M, Marcer F, Bellisario B, Gibson DI, Nascetti G. Genetic and morphological approaches distinguish the three sibling species of the Anisakis simplex species complex, with a species designation as Anisakis nascettii n. sp. for A. simplex sp. C (Nematoda: Anisakidae). J Parasitol. 2014;100:199-214.

2. Mattiucci S, Nascetti G. Advances and trends in the molecular systematics of anisakid nematodes, with implications for their evolutionary ecology and host- parasite co-evolutionary processes. Adv Parasitol. 2008;66:47-148.

3. Arizono N, Yamada M, Tegosh T, Yoshikawa M. Anisakis simplex sensu stricto and Anisakis pegreffii: Biological Characteristics and Pathogenetic Potential in Human Anisakiasis. Foodborne Pathog Dis. 2012;9(6):517-21.

4. McGladdery SE. Anisakis simplex (Nematoda: Anisakidae) infection of the musculature and body cavity of Atlantic herring (Clupea harengus harengus). Can J Fish Aquat Sci. 1986;43:1312-7.

5. Valero A, Martín-Sánchez J, Reyes-Muelas E, Adroher FJ. Larval anisakids parasitizing the blue whiting, Micromesistius poutassou, from Motril Bay in the Mediterranean region of southern Spain. J Helminthol. 2000;74:361-4.

6. Levsen A, Midthun E. Occurrence and spatial distribution of Anisakis sp. in three commercially important pelagic fish stocks from the NE Atlantic, with comments on the significance to consumer safety. Parassitologia. 2007;2: 402-3. 
7. Cipriani P, Smaldone G, Acerra V, D'Angelo L, Anastasio A, Bellisario B, Palma G, Nascetti G, Mattiucci S. Genetic identification and distribution of the parasitic larvae of Anisakis pegreffii and Anisakis simplex (s. s.) in European hake Merluccius merluccius from the Tyrrhenian Sea and Spanish Atlantic coast: implications for food safety. Int J Food Microbiol. 2015;198:1-8.

8. European Food Safety Authority, Panel on Biological Hazards (BIOHAZ). Scientific opinion on risk assessment of parasites in fishery products. EFSA Journal. 2010:8:1543.

9. Rello FJ, Adroher FJ, Benítez R, Valero A. The fishing area as a possible indicator of the infection by anisakids in anchovies (Engraulis encrasicolus) from southwestern Europe. Int J Food Microbiol. 2009;129:277-81.

10. Mattiucci S, Fazii P, De Rosa A, Paoletti M, Salomone MA, Glielmo A, De Angelis M, Costa A, Meucci C, Calvaruso V, Sorrentini I, Palma G, Bruschi F, Nascetti G. Anisakiasis and gastroallergic reactions associated with Anisakis pegreffii infection. Italy. Emerg Infect Dis. 2013;19:496-9.

11. Bao M, Pierce GJ, Pascual S, González-Muñoz M, Mattiucci S, Mladineo I, Cipriani P, Bušelić I, Strachan NJC. Assessing the risk of an emerging zoonosis of worldwide concern: anisakiasis. Scientific Reports. 2017;7:43699.

12. Moneo I, Carballeda-Sangiao N, González-Muñoz M. New perspectives on the diagnosis of allergy to Anisakis spp. Curr Allergy Asthma Rep. 2017;17(5):27.

13. Daschner A, Cuéllar C, Rodero M. The Anisakis allergy debate: does an evolutionary approach help? Trends Parasitol. 2012;28:9-15.

14. Mazzucco W, Raia DD, Marotta C, Costa A, Ferrantelli V, Vitale F, Casuccio A. Anisakis sensitization in different population groups and public health impact: A systematic review. PLoS ONE. 2018;13(9):e0203671.

15. Kruse Fæstea C, Jonscherb KR, Doopera MMWB, Egge-Jacobsenc W, Moenc A, Daschnerd A, Egaasa E, Christiansb U. Characterisation of potential novel allergens in the fish parasite Anisakis simplex. EuPA Open Proteomics. 2014;4:140-55.

16. Regulation (EC) No 2074/2005 (EC 853/2004 rev) of 5 December, 2005 laying down implementing measures for certain products under Regulation (EC) No 853/2004, Regulation (EC) No 854/2004 and Regulation (EC) No $882 / 2004$, derogating from Regulation (EC) No 852/2004 and amending Regulations (EC) No 853/ 2004 and (EC) No 854/2004, Official Journal of the European Union.

17. European Commission, 2014. Guidance Document on the Implementation of Certain Provisions of Regulation (EC) No 853/2004 on the Hygiene of Food of Animal Origin. https://ec.europa.eu/food/sites/food/files/safety/ docs/biosafety_fh_legis_guidance_reg-2004-853_en.pdf,

18. Levsen A, Lunestad B, Berland B. Low detection efficiency of candling as a commonly recommended inspection method for nematode larvae in the flesh of pelagic fish. J. Food Prot. 2005;68(4):828-32.

19. Codex Alimentarius, 2012. Code of Practice for Fish and Fishery Products. World Health Organization and Food and Agriculture Organization of the United Nations, Rome. ftp://ftp.fao.org/codex/Publications/Booklets/ Practice_code_fish/CCFFP_2012_EN.pdf,

20. Regulation EC No 178/2002 of the European Parliament and of the Council of 28 January 2002 Laying Down the General Principles and 1426 Food Anal. Methods, 2016. 9: 1418-1427 Requirements of Food Law, Establishing the European Food Safety Authority and Laying Down Procedures in Matters of Food Safety. OJEC L31, 1-24.

21. European Food Safety Authority, Panel on Biological Hazards (BIOHAZ). Scientific Opinion on the development of a risk ranking framework on biological hazards. EFSA Journal. 2012; 10(6): 2724.

22. Llarena-Reino M, Abollo E, Pascual S. A Scoring System Approach for the Parasite Predictive Assessment of Fish Lots: A Proof of Concept with Anisakids. Foodborne Pathog Dis. 2013;10(12):1067-74.

23. Rodríguez H, Abollo E, González ÁF, Pascual S. Scoring the parasite risk in highlyvaluable fish species from southern ICES areas. Fish Res. 2017:202:134-9.

24. Bush AO, Lafferty KD, Lotz JM, Shostak AW. Parasitology meets ecology on its own terms: Margolis et al. revisited. J Parasitol. 1997;83:575-83.

25. Rózsa L, Reiczigel J, Majoros G. Quantifying parasites in samples of hosts. J. Parasitol. 2000;86:228-32

26. Guardone L, Malandra R, Costanzo F, Castigliego L, Tinacci L, Gianfaldoni D, Guidi A, Armani A. Assessment of a sampling plan based on visual inspection for the detection of Anisakid larvae in fresh Anchovies (Engraulis encrasicolus). A first step towards official validation? Food Anal. Methods. 2016;1:10.

27. González-Amores Y, Clavijo-Frutos E, Salas-Casanova C, Alcain-Martínez G. Direct parasitological diagnosis of infection with Hysterothylacium aduncum in a patient with epigastralgia. Rev Esp Enf Digest. 2015;107(11):699-700.
28. Mattiucci S, Nascetti G. Molecular systematics, phylogeny and ecology of anisakid nematodes of the genus Anisakis Dujardin, 1845: an update. Parasite. 2006;13:99-113.

29. Nascetti G, Paggi L, Orecchia P, Smith JW, Mattiucci S, Bullini L. Electrophoretic studies on the Anisakis simplex complex (Ascaridida: Anisakidae) from the Mediterranean and North East Atlantic. Int J Parasitol. 1986;16:633-40.

30. Mattiucci S, Nascetti G, Clanchi R, Paggi L, Arduino P, Margolis L, Brattey J, Webb S, D'Amelio S, Orecchia P, Bullini L. Genetic and ecological data on the Anisakis simplex complex, with evidence for a new species (Nematoda, Ascaridoidea, Anisakidae). J Parasitol. 1997;83:401-16.

31. Paggi L, Mattiucci S, D'Amelio S, Nascetti G. Nematodi del genere Anisakis in pesci, cefalopodi e cetacei del Mar Mediterraneo e dell'Oceano Atlantico e Pacifico. Biologia Marina Mediterranea. 1998;5(3):1585-92.

32. Abollo E, D'Amelio S, Pascual S. Fitness of the marine parasitic nematode Anisakis simplex s. str. in temperate waters of the NE Atlantic. Dis Aquat Organ. 2001;45:131-9.

33. Mattiucci S, Abaunza P, Ramadori L, Nascetti G. Genetic identification of Anisakis larvae in European hake from Atlantic and Mediterranean waters for stock recognition. J Fish Biol. 2004;65:495-510.

34. Mattiucci S, Paggi L, Nascetti G, Portes Santos C, Costa G, Di Beneditto AP, Ramos R, Argyrou M, Cianchi R, Bullini L. Genetic markers in the study of Anisakis typica (Diesing, 1860): larval identification and genetic relationships with other species of Anisakis Dujardin, 1845 (Nematoda: Anisakidae). Syst Parasitol. 2002;51:159-70.

35. Szostakowska B, Myjak P, Wyszynski M, Pietkiewicz H, Rokicki J. Prevalence of Anisakis nematodes in fish from southern Baltic sea. Pol J Microbiol. 2005;54:41-5.

36. Timi JT, Paoletti M, Cimmaruta R, Lanfranchi AN, Alarcos AJ, Garbin L, George-Nascimento M, Rodrìguez HD, Giardino GV, Mattiucci S. Molecular identification, morphological characterization and new insights into the ecology of larval Pseudoterranova cattani in fishes from the Argentine coast with its differentiation from the Antarctic species, P. decipiens sp. E (Nematoda: Anisakidae). Vet Parasitol. 2013;199:59-72.

37. Niklitschek E. J, Secor DH, Toledo P, Lafon A, Nascimento MG. Segregation of SE Pacific and SW Atlantic southern blue whiting stocks: integrating evidence from complementary otolith microchemistry and parasite assemblage approaches. Environ Biol Fish. 2010;89:399-413.

38. Levsen A, Karl H. Anisakis simplex (s. I.) in grey gurnard (Eutrigla gurnardus) from the North Sea: food safety considerations in relation to fishing ground and distribution in the flesh. Food Cont. 2014;36:15-9.

39. Mattiucci S, Cipriani P, Paoletti M, Levsen A, Nascetti G. Reviewing biodiversity and epidemiological aspects of anisakid nematodes from the North-east Atlantic Ocean. J Helminthol. 2017:91(4):422-39.

40. Giarratana F, Panebianco F, Muscolino D, Beninati C, Ziino G, Giuffrida A Effect of allyl isothiocyanate against Anisakis larvae during the anchovy marinating process. J Food Protect. 2015;78:767-71.

41. Giarratana F, Muscolino D, Panebianco F, Patania A, Benianti C, Ziino G, Giuffrida A. Activity of $\mathrm{R}^{(+)}$limonene against Anisakis larvae. Ita J Food Saf. 2015:4(4):5499.

42. Anastasio A, Smaldone G, Cacace D, Marrone R, Lo Voi A, Santoro M, Cringoli G, Pozio E. Inactivation of Anisakis pegreffii larvae in anchovies (Engraulis encrasicolus) by salting and quality assessment of finished product. Food Cont. 2016;64:115-9.

43. Smaldone G, Marrone R, Palma G, Sarnelli P, Anastasio A. Preliminary study on the inactivation of anisakid larvae in baccalà prepared according to traditional methods. Ita J Food Saf. 2017;6:6964.

44. Regulation (EC) No 853/2004 of the European Parliament and of the Council of 29 April 2004, laying down specific hygiene rules for the hygiene of foodstuffs.

45. Regulation (EC) No 852/2004 of the European Parliament and of the Council of 29 April 2004, on the hygiene of foodstuffs.

46. Regulation (EC) No 854/2004 of the European Parliament and of the Council of 29 April 2004, laying down specific rules for the organization of official controls on products of animal origin intended for human consumption.

47. Llarena-Reino M, Piñeiro C, Antonio J, Outeiriño L, Vello C, González ÁF, Pascual S. Optimization of the pepsin digestion method for anisakids inspection in the fishing industry. Vet Parasitol. 2013;191:276-83.

48. McNemar Q. Note on the sampling error of the difference between correlated proportions or percentages. Psychometrika. 1947;12(2):153-7.

\section{Publisher's Note}

Springer Nature remains neutral with regard to jurisdictional claims in published maps and institutional affiliations. 